Proc. Estonian Acad. Sci. Biol. Ecol., 2006, 55, 4, 329-340

\title{
Spectral library of macroalgae and benthic substrates in Estonian coastal waters
}

\author{
Tiit Kutser*, Ele Vahtmäe, and Liisa Metsamaa \\ Estonian Marine Institute, University of Tartu, Mäealuse 10a, 12618 Tallinn, Estonia
}

Received 12 September 2005, in revised form 4 October 2005

\begin{abstract}
Benthic algal cover and trends in its changes are indicators of water state in coastal areas. Mapping benthic algal cover with conventional methods (diving) provides great accuracy and high resolution yet is very expensive and is limited by the time and manpower necessary to monitor large bodies of water and long stretches of coastline. Mapping of benthic macroalgal cover by remote sensing requires knowledge about optical signatures of different bottom types. We measured reflectance spectra of red, green, and brown macroalgae, seagrass, sand, pebble, and wet and dry decaying mats of macroalgae and higher plants. Comparing optical properties of the Baltic Sea macroalgae with results of other studies from different parts of the world allows us to conclude that reflectances of three large groups (red, green, and brown algae) are relatively consistent in shape. Most of the variability within the groups occurs in reflectance values. The within-species variability in reflectance values of the brown alga Fucus vesiculosus and the red alga Furcellaria lumbricalis is as great as the variability in reflectance values within brown and red algae groups, correspondingly. This suggests that the feasibility of mapping the benthic macroalgal cover in the coastal waters of the Baltic Sea by remote sensing on species level is highly unlikely. The collected spectral library of the Baltic Sea bottom types allows us to interpret remote sensing data using supervised classification methods, such as Spectral Angle Mapper, which require availability of reflectance spectra of different bottom types. The spectral library together with a bio-optical model allows estimating the suitability of different remote sensing sensors for mapping Baltic Sea bottom types. Thus, collecting the spectral library is an important step in mapping shallow water bottom types by remote sensing.
\end{abstract}

Key words: remote sensing, coastal waters, benthic macroalgae.

\section{INTRODUCTION}

Sustainable management of coastal environments requires regular collection of accurate information on recognized ecosystem health indicators (Phinn et al., 2005). Benthic algal cover and trends in its changes are indicators of water state

\footnotetext{
* Corresponding author, Tiit.Kutser@sea.ee
} 
in coastal areas. The objective of monitoring benthic algal cover in coastal areas is to detect short- and long-term changes in the species distribution and structure of coastal benthic substrate constituents. Quantitative analysis of coastal marine benthic communities enables to adequately estimate coastal marine environmental state, provide improved evidence on environmental changes, and describe processes that are conditioned by anthropogenic forces.

Mapping benthic algal cover with conventional methods (diving) provides great accuracy and high resolution (Werdell \& Roesler, 2003) yet is very expensive and is limited by the time and manpower necessary to monitor large bodies of water and long stretches of coastline. Remote sensing can potentially provide a tool for fast mapping of benthic algal cover provided the algal species are separable from each other based on their optical signatures.

Mapping of substrate cover types and their biophysical properties has been carried out successfully in optically clear, shallow coastal and reef waters (Anstee et al., 2000; Dekker et al., 2001, 2005; Phinn et al., 2005; Kutser \& Jupp, 2006). In comparison with the reflectance properties of coral reef benthic communities (Hochberg \& Atkinson, 2000, 2003; Karpouzli et al., 2004) and seagrass communities (Pasqualini et al., 1997; Fyfe, 2003), information detailing the reflectance properties of algal communities is still scanty. However, algal spectral reflectance properties have been published in some of the coral reef benthic community studies (Hochberg \& Atkinson, 2000; Kutser et al., 2000, 2003; Dekker et al., 2001). A few published reflectance spectra of various macroalgal types are presented in Maritorena et al. (1994), Anstee et al. (2000), Wittlinger \& Zimmerman (2000), and some other publications.

Remote sensing techniques have been successfully applied for operational mapping of the biophysical properties of clear waters, but turbid waters continue to represent a challenge to remote sensing techniques (Phinn et al., 2005). The Baltic Sea waters are relatively turbid and there is very little information about optical properties of benthic algae in the Baltic Sea (Siegel, 1992). The Baltic Sea is an intracontinental shallow marine environment under strong influence of human activities and terrestrial material. Its waters are often dominated by coloured dissolved organic matter (CDOM). Large discharge from rivers, limited exchange with marine waters of the North Sea, and a relatively shallow sea floor significantly influence the optical properties of the Baltic (Darecki \& Stramski, 2004).

Distribution of phytobenthic communities is determined by substrate availability, depth, and light climate on local scale and salinity on the Baltic Sea scale (Kautsky, 1988; Martin, 2000). Green algae usually occur in the shallowest part of the littoral on hard substrate. The green alga Cladophora glomerata is widespread over the Baltic Sea area and can be found in the full salinity range of the Baltic. It usually forms monodominant belts on the hard substrate close to the water edge (Söderström, 1963). Brown algae in the Baltic Sea are presented by a variety of species with morphological characteristics from ephemeral filamentous species to perennial species with large thalli. The brown alga Fucus vesiculosus is the largest macroalga found in the Baltic Sea. In areas with hard substrate with moderate 
exposure this species is very important as a habitat-forming element of the coastal ecosystem, supporting high biodiversity along rocky shores of the Western and NE Baltic. The distribution of this species in the Baltic is limited northwards and eastwards by low salinity (Fucus is usually found in salinities higher than 3-4 PSU). The unattached form of the red alga Furcellaria lumbricalis can be found in the waters of the West Estonian Archipelago on sandy gravel surfaces (Martin \& Torn, 2004). It is commercially harvested for galactans there, but is also an important habitat for fish juveniles.

The objective of this study was to determine optical properties of the species Fucus vesiculosus, Cladophora glomerata, and Furcellaria lumbricalis, selected by HELCOM (www.helcom.fi) as indicator species for the Baltic Sea, and to collect a spectral library of bottom types present in Estonian coastal waters.

\section{METHODS}

Different methods can be used to collect benthic reflectance spectra. Some authors have used underwater in situ spectrometers of their own design (Mazel, 1997; Lubin et al., 2001; Kutser et al., 2003). Others have studied coral and algal samples in the aquarium (Hochberg \& Atkinson, 2000) or measured reflectance on flow-through seawater tables (Myers et al., 1999). Some authors have used lab spectrometers and spectrometers with waterproof optical fibres to carry out measurements in the lab (Louchard et al., 2000; Zimmerman \& Wittlinger, 2000). Others have measured reflectance of reef substrates with the spectrometer on board a boat, as well as divers with fibre optics at the substrate (Holden \& LeDrew, 1998; Clark et al., 2000; Hochberg \& Atkinson, 2000). The most preferable method would be collecting reflectance spectra close to the substrate in natural conditions (Kutser et al., 2003). However, this method is not easy to use in many shallow water areas in Estonia. In many cases the measurements have to be carried out walking in shallow water. This causes resuspension of fine sediments and dramatic changes in optical water quality. Another problem is keeping the spectrometer at a fixed distance from the substrates to get a consistent spectral library. We have carried out measurements where the reflectance was measured just above the substrate and at different water depths to study how the bottom reflectance spectrum changes through the water column. However, for the collection of a spectral library of benthic macroalgae we preferred a method where samples of wet algae were measured on the shore or on board a boat as this method allows collection of a consistent set of spectra.

Reflectance spectra of benthic macroalgae were measured using a handheld GER1500 spectroradiometer. The spectral range of the instrument is $300-1100 \mathrm{~nm}$. Spectra are sampled with $1.5 \mathrm{~nm}$ intervals and the spectral resolution of the GER1500 instrument is $3 \mathrm{~nm}$. Reflectance was calculated as a ratio of the radiance from algae to the radiance from a standard Spectralon panel.

In some cases specimens of algae were collected into water-filled plastic bags. Reflectance measurements of wet algae were carried out on the shore immediately 
after the landing of the boat. In some cases reflectance spectra of wet algae were measured on board the boat immediately after collecting the specimens. Reflectance spectra of wet and dry sand, gravel, and some other material washed out to the shore were measured at their location. Multiple (at least three) reflectance spectra of each sample were measured and an average spectrum of each sample was calculated.

\section{RESULTS}

The material present near the shoreline may be quite variable. We found sandy beaches, areas covered with pebble, belts of broken shells, washed out algae and higher plants both in wet stage floating near the water line or dried in the sun on the shore. Optical properties of the material were also variable. The brightest objects in the visible part of the spectrum were broken shells, whose reflectance reached $40 \%$ near $700 \mathrm{~nm}$ and increased towards longer wavelengths (Fig. 1). Limestone pebble on the shore was the next brightest object and its reflectance was up to $22 \%$. The reflectance of wet sand on the shore was about $16 \%$ near $700 \mathrm{~nm}$. The effect of water column on substrate reflectance is clearly seen on the submerged sand spectrum in Fig. 1. Absorption by water molecules increases almost exponentially with increasing wavelength in the spectral region beyond $580 \mathrm{~nm}$. The submerged sand spectrum in Fig. 1 was measured through a water column of about $50 \mathrm{~cm}$. Decreased reflectance values (compared to wet sand on the shore) in the spectral region up to $550 \mathrm{~nm}$ are caused by absorption of CDOM in the water and at longer wavelengths by absorption by water molecules.

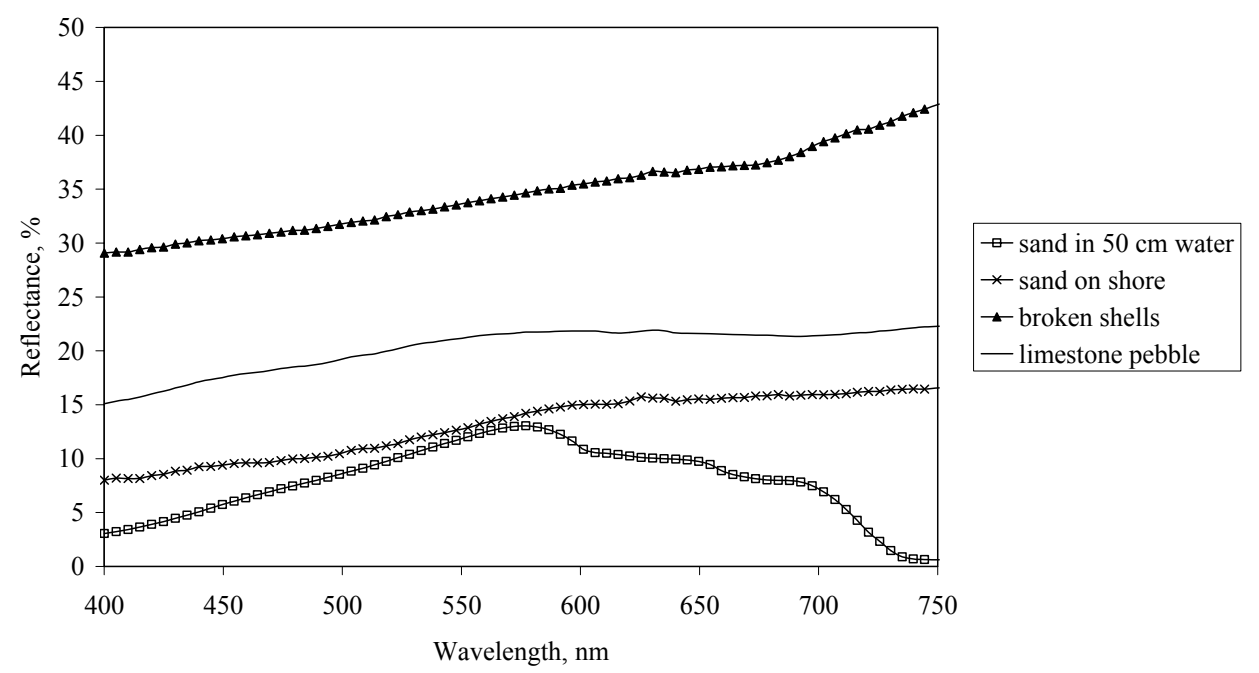

Fig. 1. Reflectance spectra of sand, broken shells, and limestone pebble on the shore and the reflectance spectrum of sand measured through a water column of $50 \mathrm{~cm}$. 
The decaying algal and plant material near the shore was relatively dark with reflectance below $6 \%$ in the visible part of the spectrum (Fig. 2). The reflectance of the floating material was similar to that of growing plants, i.e. it had a high reflectance in the near infrared part of the spectrum and the chlorophyll absorption feature was clearly seen near $680-690 \mathrm{~nm}$. The dry material on the shore, however, had lost the chlorophyll absorption feature and no sharp increase in the reflectance near $700 \mathrm{~nm}$ typical of growing plants and algae occurred.

Pebble on the shore may consist of stones of different origin. Reflectance spectra of granite (red, brown, black) measured through a water column of $5 \mathrm{~cm}$ were relatively dark (below 9\%) as seen in Fig. 3. The reflectance of greyish limestone pebble was up to $15 \%$ and that of whiter sand- or limestone rocks reached 36\%. Most of the pebble reflectance spectra were collected within $0.5 \mathrm{~m}$ radius. This means that the reflectance spectrum collected with an instrument whose spatial resolution is greater than a few centimetres would be a mixture of spectral signatures from the differently coloured pebble. Only grey limestone pebble was found covering homogeneously large enough areas that can be detected by airborne or satellite remote sensing instruments. It must be noted that nearly all sand and pebble spectra had a chlorophyll absorption feature near $680-690 \mathrm{~nm}$, which indicated presence of an algal cover on submerged stones and sand particles.

Reflectance spectra of brown algae Fucus vesiculosus were consistent in shape (Fig. 4), but variable in reflectance values. Reflectance values of dark brown parts of one Fucus specimen reached only $2 \%$ in the visible part of the spectrum whereas the maximum reflectance of top branches of the same specimen and some other Fucus specimens were between $5 \%$ and $9 \%$. The shape of the F. vesiculosus

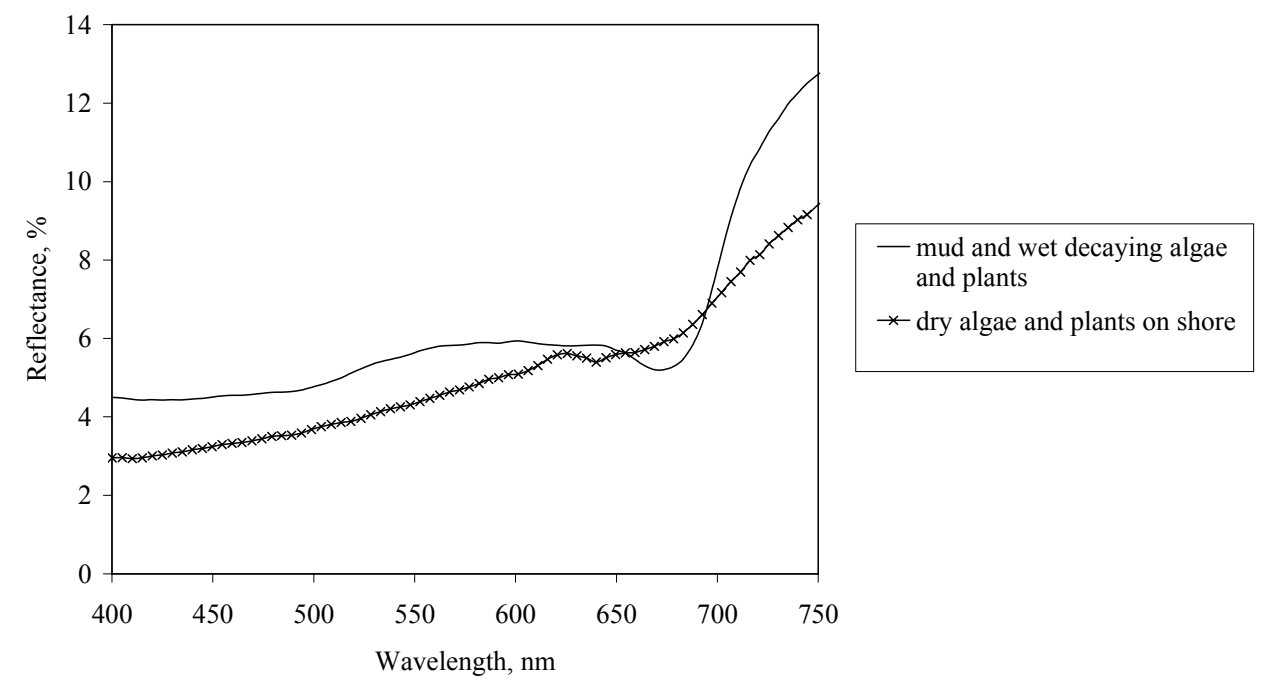

Fig. 2. Reflectance spectra of dead algae and parts of higher plants floating on the water surface and similar material that has been washed out to the shore and has dried in the sun. 


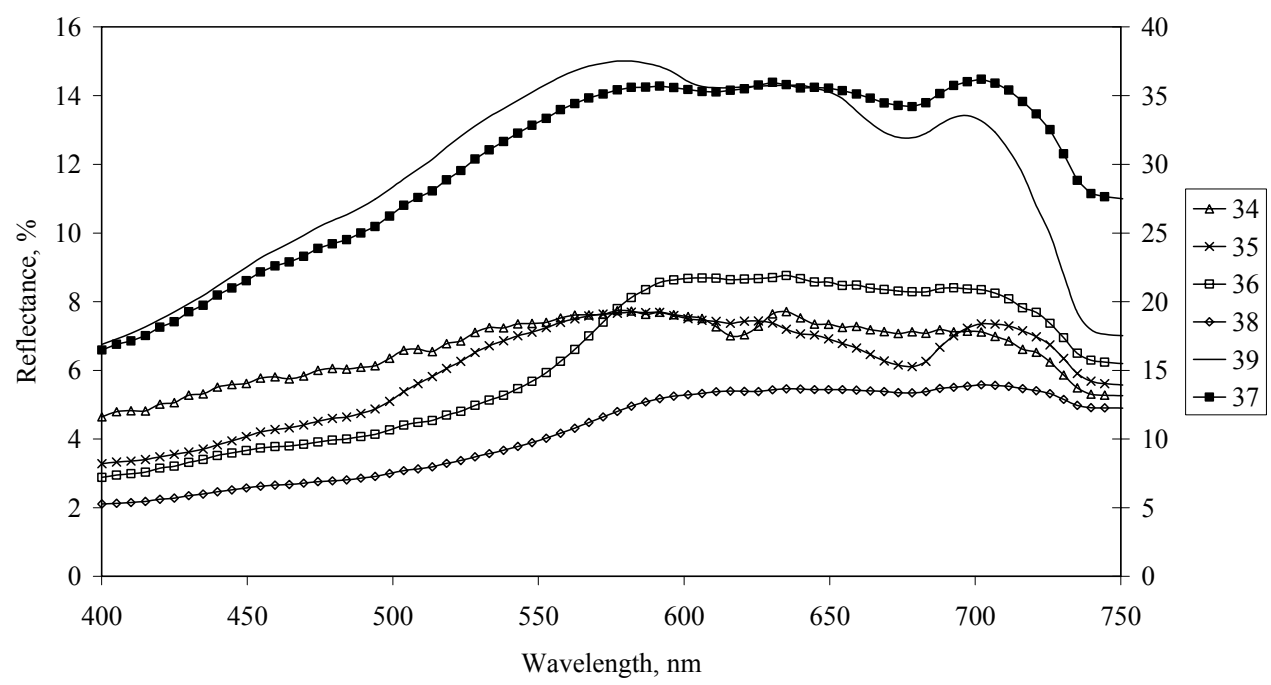

Fig. 3. Reflectance spectra of differently coloured pebble measured through a water layer of $5 \mathrm{~cm}$. Reflectance values of wet sand (sample 37) and limestone pebble (sample 39) are indicated on the right axis.

reflectance spectra is analogous to other brown algae and many corals (containing symbiotic brown algae) measured in different parts of the world (Kutser et al., 2000, 2003; Hochberg \& Atkinson, 2003), i.e. there are peaks near 600 and $650 \mathrm{~nm}$

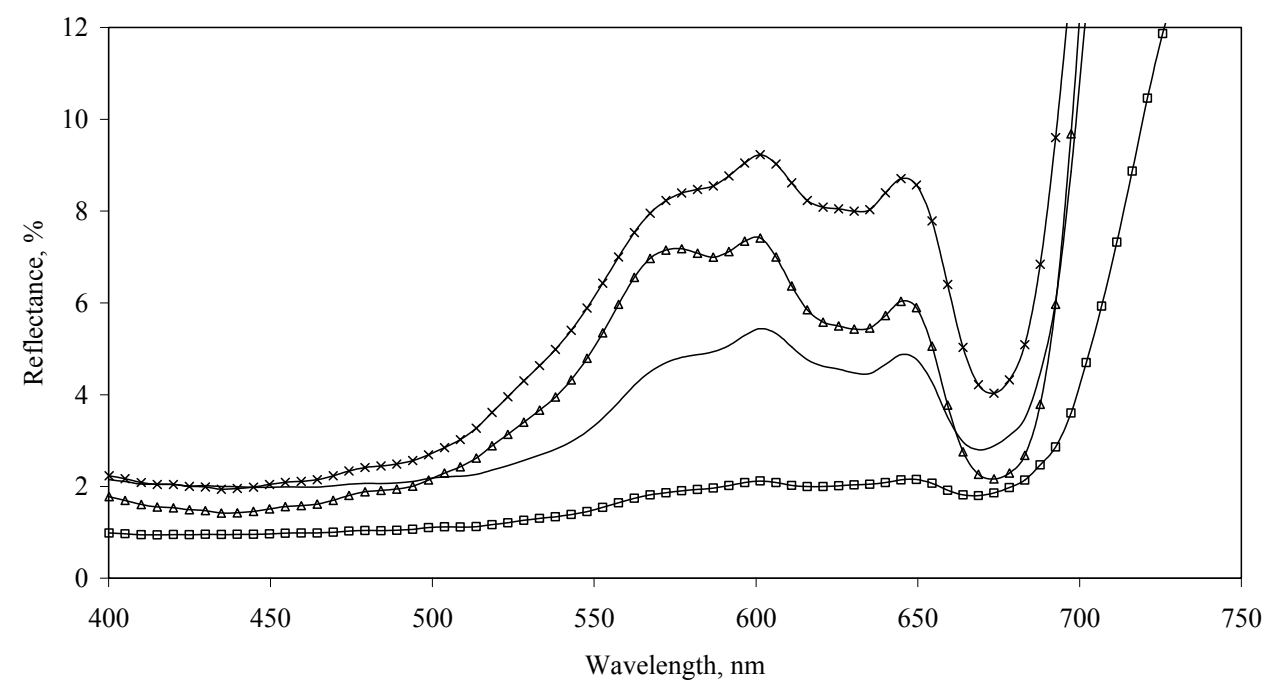

Fig. 4. Reflectance spectra of four different specimens of the brown macroalga Fucus vesiculosus. 
and a shoulder near $580 \mathrm{~nm}$. The only exceptions are reflectance spectra of F. serratus measured by Siegel (1992) in the Baltic Sea. These spectra do not contain any chlorophyll absorption feature near $680-690 \mathrm{~nm}$ present in the case of all algae. This suggest that the method used by Siegel, where the upwelling radiance sensor is just below the water surface and the downwelling irradiance sensor is just above the water surface, distorts obtained reflectance spectra in the red part of the spectrum where the water column effects on the measured signal are very high. Siegel (1992) does not describe in how deep waters the measurements were performed, i.e. how far from the benthic macroalgae the sensor was.

Reflectance spectra of red algae Furcellaria lumbricalis (Fig. 5) also resemble the reflectance spectra of other red algae collected in different parts of world oceans, i.e. there are two main peaks in their reflectance spectra, near 600 and $650 \mathrm{~nm}$. Spectrum 1 was measured above a Furcellaria patch, which was rinsed in seawater before the measurement. Spectra 2 and 3 were collected above another sample, which was covered by fine sediment and slime of decaying algae. This is probably the reason why these spectra are smoother than spectrum 1 . The upper layer of the sample (spectrum 2) had turned greenish due to extensive sunlight in the shallow water where the sample was collected. The bottom side of the same sample (spectrum 3) was darker. However, the typical double peak is seen in all reflectance spectra.

We were able to collect reflectance spectra of three different species of green algae - Chara sp., Enteromorpha sp., and Cladophora glomerata. Reflectance spectra of these species are shown in Fig. 6 together with the reflectance spectrum of the seagrass Zostera marina. The reflectance spectra shown in Fig. 6 are similar

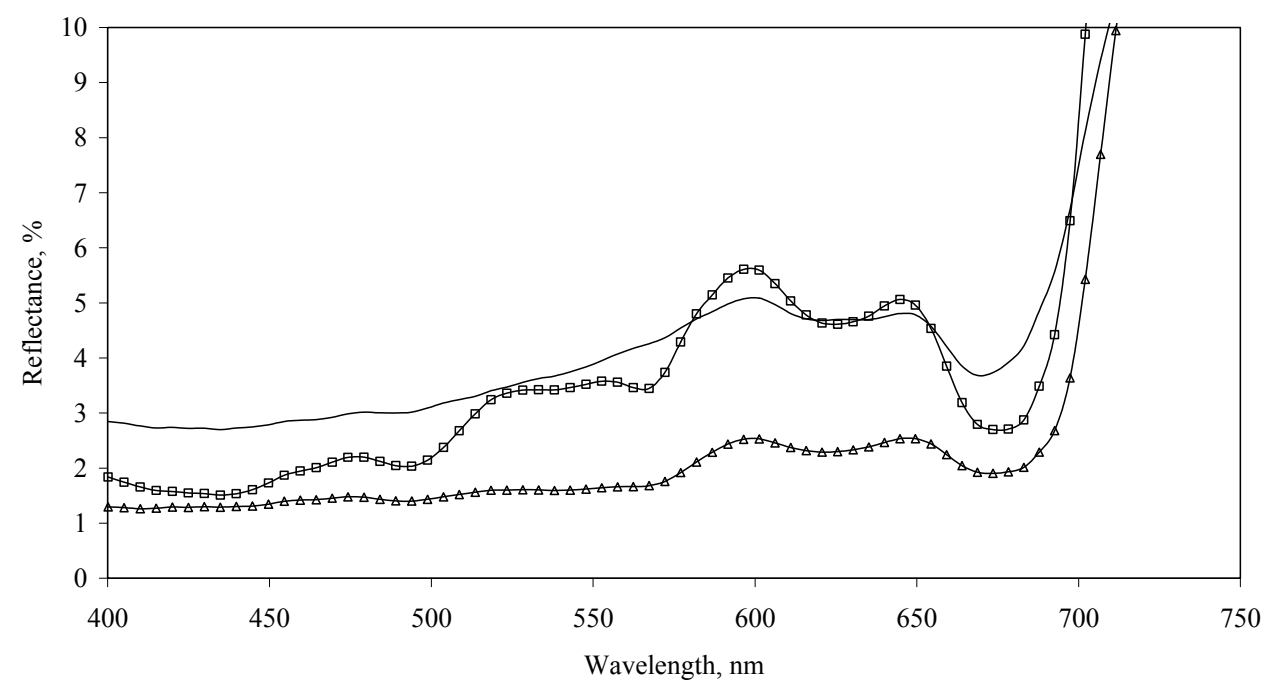

Fig. 5. Reflectance spectra of the red macroalga Furcellaria lumbricalis. 


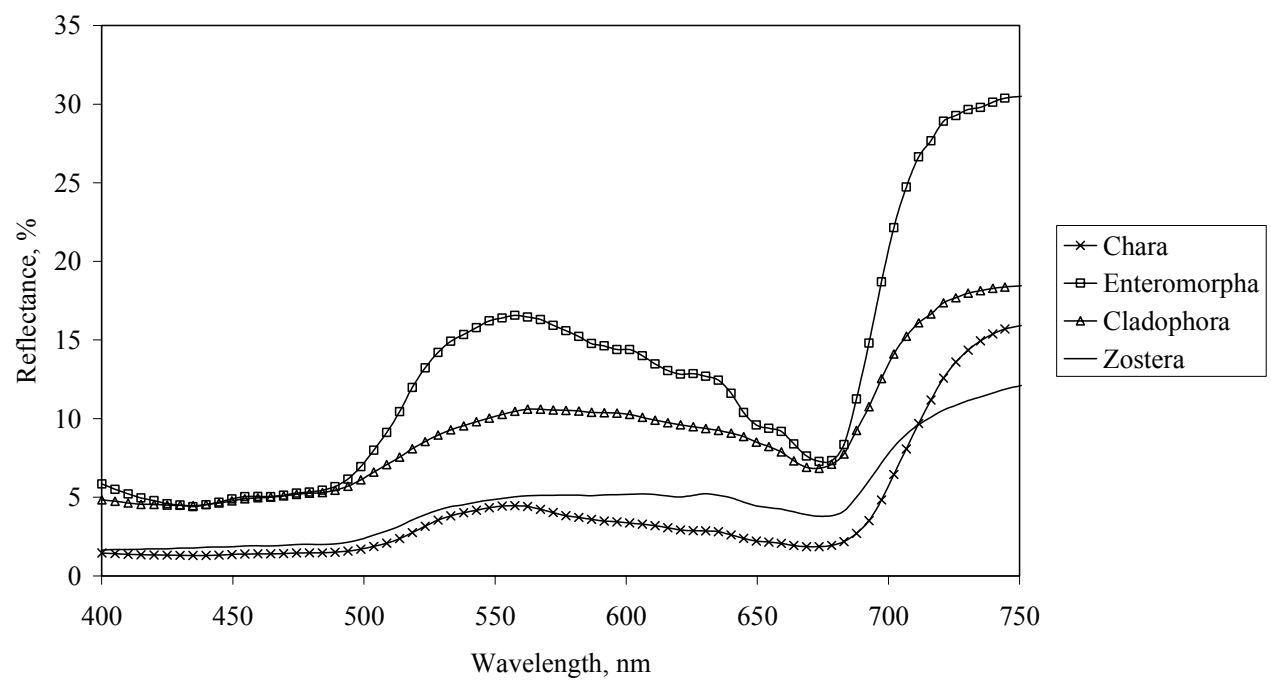

Fig. 6. Reflectance spectra of the green macroalgae Chara sp., Enteromorpha sp., and Cladophora glomerata and the seagrass Zostera marina.

to the reflectance spectra measured in different parts of the world (Siegel, 1992; Maritorena et al., 1994; Anstee et al., 2000; Kutser et al., 2000, 2003; Dekker et al., 2005).

\section{DISCUSSION}

The results showed that the reflectance spectra of red, green, and brown algae are consistent within each group. Most of the variability in each group is in reflectance values, i.e. in the brightness of the sample. Comparison of the results with the results of other studies (Siegel, 1992; Maritorena et al., 1994; Anstee et al., 2000; Kutser et al., 2000, 2003; Dekker et al., 2005) indicates that spectral features typical of these three groups of algae in the Baltic Sea are the same as in other water bodies. This means that these three broad groups of algae can be separated from each other based on their optical signatures. On the other hand, it will be practically impossible to separate algae on species level within each group with methods that use the shape of the reflectance spectra. For example, using first to fourth order derivatives has been recommended (Holden \& LeDrew, 1998; Hochberg \& Atkinson, 2000) to amplify spectral features for easier separation of different bottom types. If the main difference between algae in each group is in absolute values of the reflectance and not in the shape then peaks in derivative spectra occur at the same wavelengths and identification of different species within a group becomes unrealistic. First derivative spectra of the macroalgae studied by us are shown in Fig. 7. 


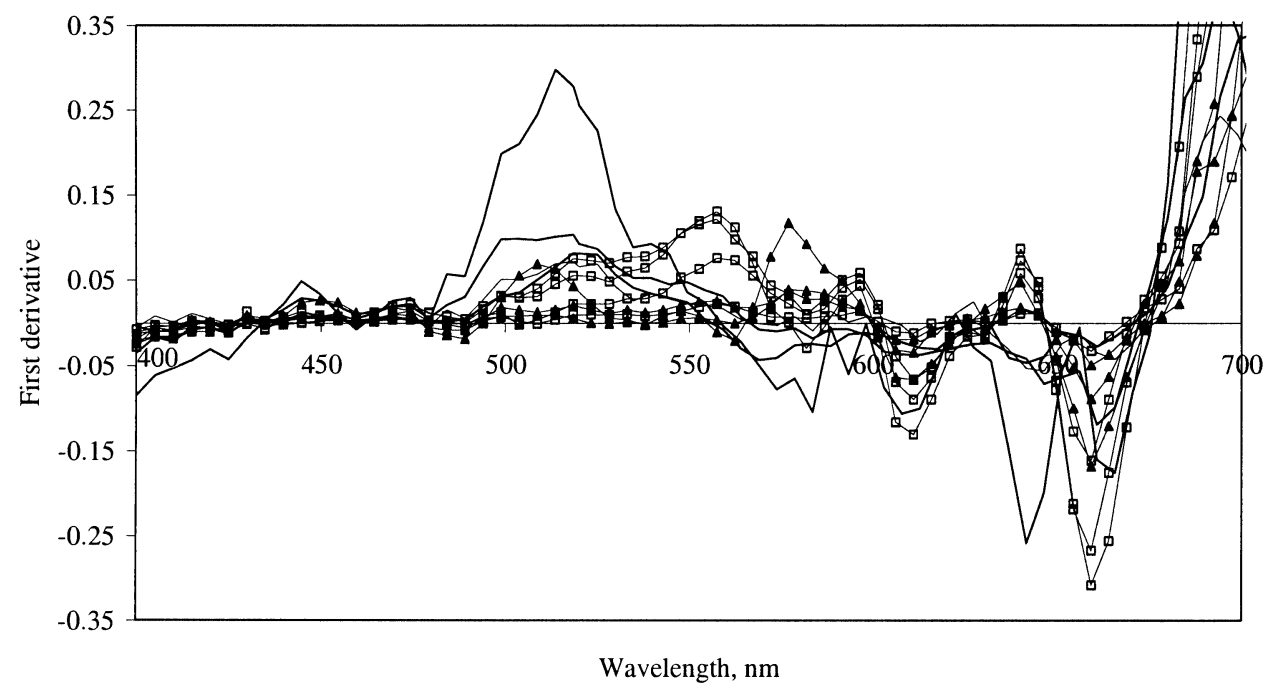

Fig. 7. First derivative spectra of green algae and seagrass (solid line), brown algae (empty squares), and red algae (full triangles).

Another method recommended for the interpretation of remote sensing data (Kutser, 2004; Kutser \& Jupp, 2006) is use of measured or modelled spectral libraries and procedures such as Spectral Angle Mapper (SAM) that compare the shape of unknown targets (i.e. pixels in remote sensing image) with reflectance spectra of known targets (i.e. measured reflectance of different algae). Being insensitive to illumination effects that are hard to remove from remote sensing imagery SAM is a powerful method for classification of remote sensing imagery. On the other hand, SAM normalizes both image and spectral library spectra before comparing them, thus removing the variability in absolute values. Consequently, if the differences between reflectance spectra within each group are in absolute values and not in spectral shape then those bottom types cannot be identified by this method.

\section{CONCLUSIONS}

Results of this study show that reflectance spectra of macroalgae of the same species are consistent in shape, but may be variable in absolute values. Comparison of the results with reflectance spectra collected in different parts of the world indicates that the reflectance of red, green, and brown macroalgae is similar within each algae group. This means that it is highly likely that macroalgae can be identified by remote sensing on these three broad group levels and not on species level.

The collected spectral library will allow us to classify hyperspectral remote sensing data, from where the atmospheric and water column effects have been 
removed, using methods like Spectral Angle Mapper. On the other hand, the spectral library together with inherent optical properties of the Baltic Sea waters and a bio-optical model allow simulation of how the reflectance spectra of different bottom types would look like through water columns of different depths. The modelled spectral library can then be used to classify bottom types and water depths simultaneously and to study capabilities of different remote sensing sensors in mapping shallow water bottom type in turbid coastal waters. Thus, collecting the spectral library of different bottom types is an important step in mapping shallow water bottom types with the help of remote sensing.

\section{ACKNOWLEDGEMENTS}

We would like to thank Georg Martin, Arno Põllumäe, and Kaire Kaljurand for their help in fieldwork. The study was funded by the Estonian Science Foundation grant 6051, Estonian State Monitoring Program, and basic funding grant 0712699s05.

\section{REFERENCES}

Anstee, J., Dekker, A., Byrne, G., Daniel, P., Held, A. \& Miller, J. 2000. Use of hyperspectral imaging for benthic species mapping in South Australian coastal waters. In 10th Australasian Remote Sensing and Photogrammetry Conference, Adelaide, pp. 1051-1061.

Clark, C. D., Mumby, P. J., Chisholm, J. R. M., Jaubert, J. \& Andrefouet, S. 2000. Spectral discrimination of coral mortality states following a severe bleaching event. Int. J. Remote Sens., 21, 2321-2327.

Darecki, M. \& Stramski, D. 2004. An evaluation of MODIS and SeaWiFS bio-optical algorithms in the Baltic Sea. Remote Sens. Environ., 89, 326-350.

Dekker, A. G., Brando, V. E., Anstee, J. M., Pinnel, N., Kutser, T., Hoogenboom, E. J., Peters, S., Pasterkamp, R., Vos, R., Olbert, C. \& Malthus, T. J. M. 2001. Imaging spectrometry of water. In Imaging Spectrometry: Basic Principles and Prospective Applications (van der Meer, F. D. \& de Jong, S. M., eds), pp. 307-359. Kluwer Academic Publishers, Dordrecht.

Dekker, A. G., Brando, V. E. \& Anstee, J. M. 2005. Retrospective seagrass change detection in a shallow coastal tidal Australian lake. Remote Sens. Environ., 97, 415-433.

Fyfe, S. K. 2003. Spatial and temporal variation in spectral reflectance: are seagrass species spectrally distinct? Limnol. Oceanogr., 48, 464-479.

Hochberg, E. J. \& Atkinson, M. J. 2000. Spectral discrimination of coral reef benthic communities. Coral Reefs, 19, 164-171.

Hochberg, E. J. \& Atkinson, M. J. 2003. Capabilities of remote sensors to classify coral, algae, and sand as pure and mixed spectra. Remote Sens. Environ., 85, 174-189.

Holden, H. \& LeDrew, E. 1998. Spectral discrimination of healthy and non-healthy corals based on cluster analysis, principal components analysis and derivative spectroscopy. Remote Sens. Environ., 65, 217-224.

Karpouzli, E., Malthus, T. J. \& Place, C. J. 2004. Hyperspectral discrimination of coral reef benthic communities in western Caribbean. Coral Reefs, 23, 141-151.

Kautsky, H. 1988. Factors Structuring Phytobenthic Communities in the Baltic Sea. Akademitryck, Edsbruk. 
Kutser, T. 2004. Quantitative detection of chlorophyll in cyanobacterial blooms by satellite remote sensing. Limnol. Oceanogr., 49, 2179-2189.

Kutser, T. \& Jupp, D. L. B. 2006. On the possibility of mapping living corals to the species level based on their optical signatures. Estuarine Coastal Shelf Sci., 69, 607-614.

Kutser, T., Skirving, W., Parslow, J., Done, T., Clementson, L., Wakeford, M. \& Miller, I. 2000. Hyperspectral detection of coral reef health. In Proc. 10th Australasian Remote Sensing Conference, Adelaide, 931-948.

Kutser, T., Dekker, A. G. \& Skirving, W. 2003. Modeling spectral discrimination of Great Barrier Reef benthic communities by remote sensing instruments. Limnol. Oceanogr., 48, 497-510.

Louchard, E. M., Reid, R. P., Stephens, C. F. \& Carney, M. 2000. Classification of sediment types and estimation of water depth using spectral libraries. In Proc. Ocean Optics XV. Monaco, CD-ROM.

Lubin, D., Li, W., Dustan, P. Mazel, C. H. \& Stamnes, K. 2001. Spectral signatures of coral reefs: features from space. Remote Sens. Environ., 75, 127-137.

Maritorena, S., Morel, A. \& Gentili, B. 1994. Diffuse reflectance of oceanic shallow waters: influence of water depth and bottom albedo. Limnol. Oceanogr., 37, 1689-1703.

Martin, G. 2000. Phtobenthic communities of the Gulf of Riga and the inner sea of the WestEstonian Archipelago. Diss. Biol. Univ. Tartu., 64.

Martin, G. \& Torn, K. 2004. Classification and description of phytobenthic communities in the waters of the West-Estonian Archipelago Sea. Hydrobiologia, 514, 151-162.

Mazel, C. H. 1997. Diver-operated instrument for in situ measurement for spectral fluorescence and reflectance of benthic marine organisms and substrates. Opt. Eng., 36, 2612-2617.

Myers, M. R., Hardy, J. T., Mazel, C. H. \& Dustan, P. 1999. Optical spectra and pigmentation of Caribbean reef corals and macroalgae. Coral Reefs, 18, 179-186.

Pasqualini, V., Pergent-Martini, C., Fernandez, C. \& Pergent, G. 1997. The use of airborne remote sensing for benthic cartography: advantages and reliability. Int. J. Remote Sens., 18, $1167-$ 1177.

Phinn, S. R., Dekker, A. G., Brando, V. E. \& Roelfsema, C. M. 2005. Mapping water quality and substrate cover in optically complex coastal and reef waters: an integrated approach. Mar. Pollut. Bull., 51, 459-469.

Siegel, H. 1992. On the influence of sediment and phytobenthos on spectral reflectance at the sea surface. Beitr. Meereskd., 63, 91-104.

Söderström, J. 1963. Studies in Cladophora. Bot. Gothenburg., 1, 1-147.

Werdell, P. J. \& Roesler, C. S. 2003. Remote assessment of benthic substrate composition in shallow waters using multispectral reflectance. Limnol. Oceanogr., 48, 557-567.

Wittlinger, S. K. \& Zimmerman, R. C. 2000. Hyperspectral remote sensing of subtidal macroalgal assemblages in optically shallow waters. In Proc. Ocean Optics XV. Monaco, CD-ROM.

Zimmerman, R. C. \& Wittlinger, S. K. 2000. Hyperspectral remote sensing of submerged aquatic vegetation in optically shallow waters. In Proc. Ocean Optics XV. Monaco, CD-ROM.

\section{Merepõhja ja põhjataimestiku optilised omadused Eesti rannavetes}

\section{Tiit Kutser, Ele Vahtmäe ja Liisa Metsamaa}

Muutusi põhjataimestiku kooslustes on võimalik kasutada, hindamaks rannikumeres toimuvaid keskkonnamuutusi. Põhjataimestiku kaardistamine sukeldujate abil on äärmiselt töömahukas ja kallis. Uurimaks kaugseire kasutamise võimalusi 
põhjataimestiku kaardistamisel Läänemeres, on vaja teada erinevate põhjatüüpide (vetikad, liiv, kruus jne) optilisi omadusi. Käesoleva töö eesmärgiks oli koguda Eesti rannikumeres esinevate põhjatüüpide heleduskoefitsientide spektriteek. Meie poolt mõõdetud ja mujal maailmas kogutud analoogsete andmete võrdlus lubab oletada, et puna-, rohe- ja pruunvetikate heleduskoefitsientide kuju iga rühma sees on suhteliselt sarnane. Põhilised erinevused on heleduskoefitsiendi väärtustes ehk objektide heleduses. Kuna ühe liigi piires on heleduskoefitsiendi väärtuste varieeruvus samas suurusjärgus eri liikide heleduste varieeruvusega, siis võib järeldada, et kaugseire abil ei ole võimalik põhjataimestikku liikide tasemel kaardistada, vaid ainult kolme suure rühma tasemel. Kogutud spektriteeki saab kasutada põhjataimestiku kaardistamiseks kaugseire abil, kasutades selleks klassifitseerimismeetodeid, mis põhinevad tundmatute objektide (kaugseire piksel) ja tuntud objektide (mõõdetud või modelleeritud heleduskoefitsiendi spekter) võrdlusel. Ka võimaldab kogutud spektriteek koos biooptilise mudeliga hinnata, kas ja millised kaugseire sensorid on sobilikud põhjatüüpide kaardistamiseks sellistes hägusates veekogudes nagu Läänemeri. 